УДК 1:311

DOI: 10.18101/1994-0866-2020-2-68-72

\title{
МОРАЛЬНАЯ СОСТАВЛЯЮЩАЯ В ТЕОРИИ ЭЛИТ
}

\section{(C) Серебрякова Юлия Александровна}

доктор философских наук, профессор, Бурятская государственная сельскохозяйственная академия имени В. Р. Филиппова Россия, 670024, г. Улан-Удэ, ул. Пушкина, 8

E-mail: serebr.yu,a@yandex.ru

\author{
(C) Васюткин Гэсэр Александрович \\ аспирант, \\ Бурятская государственная сельскохозяйственная академия имени В. Р. Филиппова \\ Россия, 670024, г. Улан-Удэ, ул. Пушкина, 8 \\ E-mail: v.geser@mail.ru
}

Статья посвящена моральной составляющей теории элит. Анализируется одно из основных значений термина «элита», место моральных оценок в интерпретациях элиты в истории социально-философской мысли, в том числе во взглядах Конфуция, Т. Мора, Г. В. Ф. Гегеля, Н. А. Бердяева, а также в рамках ценностного подхода к элитологии. Этот подход выявляет существенные черты в представлениях об элите современного общества. Отмечается, что некоторые моральные качества, считавшиеся ранее атрибутивными для элиты, становятся качествами более широких социальных слоев. Таким образом, моральная составляющая понятия элиты в настоящее время приобретает большую значимость и характеризует более широкий круг индивидов и социальных групп, чем в период становления элитологии.

Ключевые слова: элита; элитность; элитология; политическая элита; ценностный подход; гражданское общество; моральное качество; государство; аристократия; власть.

\section{Для цитирования}

Серебрякова Ю. А., Васюткин Г. А. Моральная составляющая в теории элит // Вестник Бурятского государственного университета. Философия. 2020. Вып. 2. С. 68-72.

Понятие «элита» широко обсуждается и исследуется в российской и зарубежной научной литературе. Понятия «элита», «элитность», «элитизм» и т. п. являются объектом сравнительно молодой научной дисциплины «Элитология», в которой объединены научные знания политологии, социальной философии, культурологии, социальной психологии и т. д.

Термин «элита» происходит от лат. слова eligere, затем трансформировавшегося во французское слово elite - лучший, избранный, отборный. Первоначально этот термин появился и использовался по преимуществу в отношении церковной иерархии (избрание епископов, папы) [1, с. 58]. Большинство теоретиков, следуя этимологии этого слова, отмечают в основном два его значения: лучший и отборный, избранный.

В первом из них очевидна идеализация элиты, а также моральные основания оценки. В этом же ключе Г. В. Ф. Гегель называл крупное дворянство и верхушку чиновничества «всеобщим сословием», которое, как он полагал, бескорыстно представляет интересы всех сословий. 
Между тем бескорыстие - одна из высших моральных ценностей - не слишком популярно в условиях малоцивилизованного рынка, было мало востребовано в дискурсе советского периода, хотя многие честные труженики вполне бескорыстно отдавали на благо общества свои ресурсы (физические и духовные силы, время, дарования и т. д.). По призыву партии они постоянно участвовали в помощи СССР многим странам и народам, политическим деятелям и движениям, более или менее идеологически близким и даже в некоторой мере демократическим.

Однако в этической теории тех лет, основанной на постулатах экономического детерминизма, концепт «бескорыстие» практически отсутствовал. Не случайно соответствующей статьи нет ни в одном из словарей по этике. Среди моральных принципов, раскрывающих отношение индивида к собственности, большая часть имеет негативные коннотации: корыстолюбие, потребительство, скупость, и лишь бережливость трактуется как позитивное моральное качество ${ }^{1}$.

Моральная составляющая представлена в теории элит Г. Моска, который утверждал, что в культурных обществах элита стремится так или иначе обосновать свое обладание властью, в том числе морально и юридически [2, с. 138].

На некоторые моральные критерии, необходимые для идентификации элиты, указывал М. Вебер, считая решающими такие, как самоотдача, чувство ответственности за дело своей жизни, а также «способность с внутренней собранностью и спокойствием поддаться воздействию реальностей...» [3, с. 22].

М. Вебер, исследуя бюрократию, ее функции и роль в социуме, дифференцировал ее представителей на специалистов и политиков, наделял их моральными качествами: добросовестностью, точностью, исполнительностью - первых, и ответственностью - вторых.

Один из основных подходов к определению сущности элиты — ценностный, или меритократический, согласно которому элита - это превосходящая по своим качествам другие социальные группы, стоящая над массами. Представители этого подхода - В. Парето, Н. А. Бердяев, Х. Ортега-и-Гассет и др. Среди критериев принадлежности к элите выделяют и моральные качества ее представителей: требовательность к себе, волю, стремление к самосовершенствованию, духовное благородство и т. д.

Ярким представителем этого похода был Н. А. Бердяев, исходивший из второго значения термина «элита» - избранность. «Нравственный закон истории проявляется через качественный подбор личностей, через избранные личности» $[4$, c. 101].

Результат этого подбора — «аристократия», обладающая такими моральными качествами, как духовное благородство, сознание своего достоинства, способность «служить человеку и миру», жертвенность, щедрость и др. [4, с. 128].

Все эти качества можно обозначить словосочетанием «лучший из лучших». Помимо положительных некоторые мыслители выделяли и негативные свойства элит. Так, например, Ч. Р. Миллс в книге «Властвующая элита» при анализе циркуляции элит рассматривал то основное условие, которое помогает субъекту стать

\footnotetext{
${ }^{1}$ Словарь по этике. М.: Политиздат, 1983. С. 26, 145, 268, 320.
} 
частью элиты: это беспринципность, т. е. аморальное качество, а также умение быть полезным начальству.

Ч. Р. Миллс разделил критиков элиты на две группы: первые - те, кто исходит из морали, вторые - те, кто исходит из зависти. Первые не стремятся стать частью элиты, а вторые желают, но им этого не удается.

Особенностью отечественной культуры, в том числе русской философскокультурологической мысли, является её сконцентрированность на проблематике духовности и нравственности, одним из важнейших аспектов которой является культ «лучших людей» (Ф. М. Достоевский), не только непрестанно совершенствующихся, но и посвящавших себя людям, обществу, Отчизне.

«Лучшие люди» - синоним духовной элиты, которая «есть не столько коллективное образование или групповая общность особо одаренных и избранных людей, сколько единичное, исключительное явление отдельных выдающихся личностей, деятельность которых непосредственно осуществляется в формате координат функционирования отечественной культуры», - утверждает С. С. Комиссаренко [5, с. 13].

Справедливо уточнить, что творчество корифеев отечественной культуры, от Пушкина до Солженицына и Сахарова, вышло далеко за пределы формата отечественной культуры и стало достоянием и европейской, и мировой культуры.

Современные исследователи также обращают внимание на моральные качества представителей элиты. «Элита - это личности или группы личностей особого специального достоинства, это те, кто строг и требователен к себе самому, берет на себя труд и долг», — пишет А. Е. Чирикова [6, с. 149].

Н. Б. Карабущенко, рассматривая понятие элитности как «внутренней самости» элиты, утверждает: «Элитность есть конкретное качество личности, придающее ей уникальный характер. Это максимальное развитое достоинство личности, свидетельствующее о ее самодостаточности и общественной важности. К сожалению, не все VIP-персоны обладают этим качеством. Чаще всего мы судим об этих людях по их статусу, а не по достоинству, которого может и не быть» [7, с. 21]. Исследователь правильно полагает, что данная категория выражает сущность духовного развития личности, находящейся в процессе поэтапного восхождения к своему идеалу. Следовательно, подлинная элитность немыслима без духовного возвышения человека, в том числе его нравственного совершенствования.

Ценностные теории элиты и даваемые в их рамках ее определения объединяет утверждение, что элита есть сообщество наидостойнейших во всех отношениях, в том числе и моральном, представителей общества, обладающих наиболее выдающимися способностями в различных сферах. Сторонники данной концепции убеждены, что вхождение в элиту — не произвольный или насильственный процесс, а результат естественного отбора, процесса приобщения наиболее одаренных личностей к рычагам управления.

Вместе с тем многие мыслители, среди которых Конфуций, Платон, Аристотель, Августин Блаженный, Ф. Аквинский, Н. Макиавелли, Т. Мор, В. Парето и др., отмечали пороки представителей элиты, а большинство критиковало их за это.

Так, за постоянным и детальным описанием Конфуцием того, каким должен быть благородный муж, что и как он должен делать (держаться золотой середины, не быть безрассудным, признавать справедливость за основу, проявлять уступчивость, совершенствоваться посредством искренности, жить в согласии с другими 
людьми и т. д.), просматривается подспудное и деликатно выраженное желание мыслителя видеть эти качества в представителях высших сословий.

Т. Мор более прямолинейно и откровенно характеризует представителей правящей элиты как бесчестных, хищных, одержимых гордыней, «под предлогом и под именем государства думающих о своих выгодах» [8, с. 276-278].

Критерий элитности «лучший», а по Н. А. Бердяеву «лучший из лучших», в разные времена воспринимался и ныне воспринимается как слишком субъективный и не вполне отвечающий строгости научного дискурса.

Может быть, поэтому в истории социально-гуманитарной мысли этот смысл термина «элита» был дополнен другим, более реалистическим и прагматическим, обозначающим высшую правящую группу.

Несмотря на то, что ценностный подход критикуют за идеализацию качеств элиты и преувеличение ее роли в обществе, благодаря ему улавливается нечто существенное в природе элиты, в том числе атрибутивность в представлении о ней и об элитности нравственно-волевого признака [9, с. 94], более того, по нашему мнению, — решающей роли моральной составляющей.

В процессе модернизации общества все более широкие слои населения, чем наследственная элита, получают возможность приобретать качества, ранее считавшиеся присущими только элите: образованность, профессионализм, общая культура, хорошие коммуникативные навыки и т. д.

Все больше людей становятся интеллектуалами, специалистами в сфере информационных технологий, топ-менеджерами и т. д., показывают себя как интеллигентные, зрелые члены гражданского общества.

Среди этих качеств новых представителей элиты значительна доля нравственно-волевых качеств. В то же время, согласно утверждениям В. Парето, потомки высших слоев теряют элитные свойства. В элитной среде, считает мыслитель, не может сколько-нибудь долго сохраняться соответствие дарования статусу.

Хотя в современной элитологии прослеживается тенденция сужения понятия «элиты» до политической элиты [10, с. 75], полагаем, что новые тенденции тоже надо учитывать, а они свидетельствуют о возрастании роли интеллектуальной, творческой, технической и технологической элиты. К тому же в развитых государствах в политической сфере все большее влияние имеет гражданское общество, и политической элите приходится с этим считаться.

Таким образом, моральная составляющая понятия элиты в настоящее время приобретает большую значимость и характеризует более широкий круг индивидов и социальных групп, чем в период становления элитологии.

\section{Лumepamypa}

1. Элитизм в России: «за» и «против»: сб. материалов интернет-конференции, февраль — май 2002 г. / под общ. ред. В. П. Мохова. Пермь: Изд-во Пермского гос. техн. унта, 2002. $275 \mathrm{c}$.

2. Моска Г. Элементы политической науки // Социологические исследования. 1995. № 4. C. 138-146.

3. Антология мировой политической мысли. Т. 2: Зарубежная политическая мысль. ХХ в. / рук. проекта Г. Ю. Семигин; отв. ред. Т. А. Алексеева; ред.-сост. Г. К. Ашин, Е. Г. Морозова. М.: Мысль, 1997. 832 с.

4. Бердяев Н. А. Философия неравенства. М.: ИМА Пресс, 1990. 288 с. 
5. Комиссаренко С. С. Российская элита как предмет отечественной культурологии // Вопросы культурологии. 2007. № 7. С. 13-18.

6. Чирикова А. Е. О теориях элит // Общество и экономика. 2008. № 3-4. С. 144-174.

7. Карабущенко Н. Б. «VIP» // Гуманитарные исследования. 2005. № 3. С. 21-27.

8. Мор Т. Утопия. М.: Наука, 1978. 417 с.

9. Карабущенко Н. Б., Иващенко А. В. Элита: психологическая сущность, критерии, типологические особенности // Вестник РГНФ. 2010. № 4. С. 93-104.

10. Мелешкина Е. Ю. Социальная стратификация и политическая элита // Политический процесс: основные аспекты и способы анализа: сб. учеб. материалов / под ред. Е. Ю. Мелешкиной. М., 2001. С. 75.

\section{MORAL COMPONENT IN THE ELITE THEORY}

Yulia A. Serebryakova

Dr. Sci. (Philos.), Prof.,

Filippov Buryat State Agricultural Academy

8 Pushkina St., Ulan-Ude 670024, Russia

E-mail: serebr.yu, a @yandex.ru

Geser A. Vasyutkin

Research Assistant,

Filippov Buryat State Agricultural Academy

8 Pushkina St., Ulan-Ude 670024, Russia

E-mail: v.geser@mail.ru

The article is devoted to the moral component of the elite theory. We have analyzed one of the main meanings of the term "elite", the place of moral assessments in interpretations of the elite in the history of socio-philosophical thought, including the views of Confucius, Th. More, G. W. F. Hegel, N. A. Berdyaev, as well as within the value-based approach in elitology. This approach reveals the significant features in the ideas about the elite in modern society. It is noted that some moral qualities that were previously considered attributive to the elite become qualities of wider social strata. Thus, the moral component of the concept of elite is currently gaining more importance and characterizing a wider range of individuals and social groups than during the formation of elitology.

Keywords: elite; elitism; elitology; political elite; value-based approach; civil society; moral quality; state; aristocracy; power. 